\title{
A STUDY OF ERRORS IN THE THIRD SINGULAR PRONOUNS OF SIMPLE PRESENT TENSE BY USING INTERLANGUAGE ANALYSIS AS AN APPROACH. A CASE STUDY
}

\author{
Salmon Pandarangga \\ (spsumba@gmail.com) \\ STIE Kriswina Sumba
}

\begin{abstract}
The purpose of this study is to analyze factors contributing to errors made in learning English as a target language (TL). Employing a case study research, the participant was interviewed for approximately 30 minutes about daily activities and experiences in learning English. This research focuses in analysing the participant's use of third singular pronoun in simple present tense. The findings revealed that errors made by TL learners are mainly influenced by some factors related to their TL's and native language's (NL) knowledge, systems and rules. These factors are coexisted and interconnected in TL learners' minds. This is against Robert Lado's argument which mentioned that learner made errors in TL learning because of the interference from NL. The study provides pedagogical implications that TL teachers should perceive errors made by the learners as a sign of language learning and development; therefore they should not be discouraged to learn. Also, TL teachers should be aware of their very important roles to help, to guide and to lead the learners' progress in learning the TL. The future subsequent studies should consider of involving more sample size over a longer period of time as to obtain to a more generalized finding.
\end{abstract}

Key words: errors, interference, interlanguage

\section{INTRODUCTION}

Target language (TL) learning is often challenging for learners. This is because of the vast differences between their native language and the TL in terms of rules, forms and knowledge. Some learners find learning fun while 
others find it frustrating. Learners exert considerable effort to become competent speakers or even to emulate native speakers. For example, they strive for perfect pronunciation.

In their efforts to learn the $\mathrm{TL}$, learners usually make errors. Some teachers strongly believe making mistakes is an important part of the learning process and that it enables learners to improve their TL skills. Other teachers perceive errors negatively as obstacles in learning, and therefore believe errors need to be eliminated. These teachers have limited tolerance with learners who make errors. Other teachers might ignore errors, or they simply do not know how to address them.

It is widely assumed that errors occur because of the interference of NL and the degree of difference between TL and NL. It appears that learners transfer rules, forms and knowledge of NL to TL. For example, learners in Indonesia might believe that the rules, forms and knowledge of Bahasa Indonesia are similar to English.

Some theorists consider errors as a learning process. It demonstrates the mind's ability to adapt, transform and restructure NL and TL language systems to a new language system. These theorists also believe that errors are reflections of the learner's efforts to comprehend the TL systems and knowledge. In other words, the errors are reflections of a new language system being constructed. This new system combines elements of both the NL and the TL. Therefore, it is strongly argued that TL learners make errors as efforts to construct a new language system which is somehow different from the system of NL and TL and not interference of NL to TL. This paper is intended to analyze factors contributing to errors made in learning English as a foreign language.

\section{THEORETICAL FRAMEWORK}

This theoretical framework will be divided into two sections. While the first section discusses the errors, types of errors and the reasons to make errors; the second discusses the theoretical approaches e.g. Contrastive Analysis (CA), Error Analysis (EA) and Interlanguage Analysis (IA). The CA and EA have important role to explain the process of interference from NL to TL. Also the CA and EA, at some point, have significantly contributed to establish and emerge an integrated theory, that is, interlanguage 
theory (Mizuno, 1991). Hance, it is thought that to have a clear understanding about the interlanguage process, it is important to put into consideration the CA and EA theories.

Definition of errors, types of errors and reasons to make errors What are errors?

According to Ellis (2003) “errors reflects gaps in learner's knowledge; this occur because the learner does not know what is correct." (p.17). He further stated that if the learner in his or her performances of TL language consistently kept using the deviated words, then it would be considered as a little knowledge of the TL. Moreover, it is believed that there are three kinds of errors based on their systematics (Corder, 1974 as cited in Ellis, 1994, p. 56):

1. Pre-systematic errors occur when the TL learners are not aware of the existence of a certain system in the TL.

2. Systematic errors occur when the TL learners constructed and use a system; however the system is not the right one.

3. Post-systematic errors occur when the TL learners understand and know the correct system but fail to use it consistently.

It seems that the errors occur because a learner has not yet fully understood and applied the system of TL (Ellis, Ibid).

\section{Source of errors}

According to Ellis (2003) there are three sources of errors, which are transfer, overgeneralization and omission. In transfer errors, the learners tend to use their NL knowledge to the TL. In overgeneralization errors, the learners appear to overgeneralise forms of the TL e.g. the use of 'drinked' for 'drank'. However, in omission errors, the learners tend to simplify the forms of the TL, for example, 'three apple' instead of 'three apples'.

\section{Why people make errors?}

According to Lado (as cited in Steilen, 2005) errors are made 
because the learners are influenced by the NL knowledge in which the learners just simply transfer the NL systems and knowledge to TL. However, some theorists (Ellis, 1994; Ellis, 2003; Lightbown \& Spada, 1993; Mizuno, 1991) considered errors as learners' efforts to systematically construct and establish new systems of a language in which the new systems are someway different either from the TL or NL. Moreover, Corder (1967) suggested that errors are important evidence that the TL learners are in a process of acquiring TL. In other words, errors reflect the stage of systematic language development that the TL learners have reached (Ellis, 2003).

\section{Theoretical Approaches: Contras-} tive Analysis, Error Analysis and Interlanguage Analysis

This research discusses three theories to determine whether the errors occurs a way of transferring knowledge from NL to FL or as a part of constructing a new system of language. These theories can help to answer how and why the errors occur.

\section{Contrastive Analysis (CA) and} Error Analysis (EA)

Before 1970, most of the theorists relied on CA to investigate the errors made by the TL learners. Even though, CA was first introduced by Lado, it was an impetus of behaviourist theory. CA was used on the basis of identifying habit formation (VanPatten \& Benati, 2010), for example, similarities and differences of NL and TL. Moreover, CA also predicted the potential errors in TL produced by the learners (Lightbown \& Spada, 1993). By predicting the potential errors in TL, the learners might be able to identify the error patterns in TL (Lado, 1957 as cited in Steilen, 2005; Hyltenstam \& Pienemann, 1985).

Also, Lado (as cited in Gass, M.S., \& Selinker, L., 2009) stated clearly that "individuals tend to transfer the forms and meanings, 
and the distribution of forms and meanings of their native language and culture to the foreign language and culture-both productively" (p.2). It can be said that the learners transfer directly the rules of NL to TL. For example, Indonesian speakers might express 'I sleep' in English as this expression translated directly in Indonesian, 'Saya tidur'. In other words, at some extent, these two languages have some similarities on the basis of language knowledge for example, verbs always come after subjects.

However, if there are differences between NL and TL, there would be possibility of TL learners to make the errors (Lightbown \& Spada, 1993). Lightbown and Spada gave example of the differences of English speakers who learn French or French speakers who learn English might possibly lead to errors on the basis of parallel linguistic features. They illustrated clearly that in English, direct objects whether noun or pronoun, follow the verb e.g. "The cat eats the cookie, the cat eats $i t^{\prime \prime}$. In French, nouns of direct objects come after the verb e.g. "Le chat mange le biscuit"-literally, "The cat eats the biscuit. However, pronouns of direct objects come before the verb, for example, "Le chat le mange"literally, "The cat it eats". It is thus CA would predict that the speakers of French who learn English might say: "The cat it eats" while the English speakers might say: "Le chat mange $l e "$. The CA is based on three general assumptions (Mizuno, 1991; Gass \& Selinker, 2009):

1. It is claimed that language is a matter of habit, then; learning of TL is an effort to establish a new set of habits.

2. The interference of NL to TL is the main cause of errors and difficulties in the production and/ or reception of learning the TL.

3. The degree of learning difficulties of TL may determine a number of errors produced by the learners. In other words, the smaller the 
differences, the less the errors may occur.

Even though, the CA has some limitations the fact that it just predicts the learning difficulties in $\mathrm{TL}$, it provides some contribution to TL learning by providing some guidelines instruction to deal with difficulties by errors in TL (Mizuno, 1991).

After 1970, some theorists raised concerned thoughts whether the errors made by the learners were merely transferring the knowledge of NL to TL or trying to construct a new system of language. Another concerned thought was that the adult learners of TL and the young learners of NL had remarkably similar kinds of errors. For example, both learners would tend to add -ed of past tense in irregular verbs e.g. writed instead of wrote. In other words, when the learners of TL used writed instead of wrote, actually, the learners tried to construct their own system of language which would be different from the NL and TL.
In order to have more effective method to investigate the errors, some theorists introduced a new method, errors analysis (EA). EA approach emphasised on how to identify and analyse different kinds of errors as efforts to understand how and why the errors occurred (Lightbown \& Spada, 1993). They clearly stated that " errors analysis was based on the assumption that the speech of second language learners is a system in its own right-one which is rule-governed and predictable and very much like the system of young first language learners" (55). They further claimed that these errors reflected the learners' efforts to comprehend the TL system. Similarly, Susan and Selinker (2001) believed that EA more focused on detailed description and analysis of different kinds of errors produced by the TL learners. They further stated that the errors made by the learners in TL were compared with the form of TL itself. Like Susan and Selinker, Mizuno (1991) also believed that EA emphasised on 
errors production such as sounds and sentences produced by the TL learners. However, as Mizuno continued, EA and also CA tended to neglect the internal process of learning TL, for example, how and why the errors occurred.

The similarities and differences between these two theories are obvious. CA and EA had similarity on the basis of production but difference on errors investigation. Both theories investigated and analysed the errors the learners made on the basis of production. However, while in CA tended to compare the errors between the NL and TL forms, EA tended to compare the errors the TL learners made with the forms of TL. It can be seen that even though both CA and EA had different approaches to investigate the errors, both theories shared similarities as they focused on the errors production rather that internal process of errors.

\section{Inter-language theory}

In order to know and understand how and why the errors occurred internally, Larry Selinker (1972) proposed interlanguage theory. Unlike CA and EA theories, interlanguage theory emphasised on the process of how and why human beings make errors internally. It can be said that the focus of this theory is predominantly about human cognition, the knowledge of language and the process of acquiring the language (Langacker, 1987\& Newson, 2007). Moreover, Cook (1988) believed that there are systematic and internal structures in human minds that make them able to construct, articulate and use the languages. In other words, the construction and use of language reflects the internal structure of human mind (Cook, 1993; Ellis, 2003; Lyons, 1977; Pienemann, 2003).

In addition, it is argued that in the NL speakers' minds, they know subconsciously rather than consciously the knowledge of their own NL systems (Radford, 2004). In other words, this subconscious knowledge of language systems are 
"not learnt but already present in the mind" (Cook, 1988, p. 170). Chomsky (as cited in Radford 2004) called the subconscious language systems in speakers' minds as internalized linguistic systems. Chomsky further argued that the internalized linguistic systems "are humanly accessible under normal condition or can be acquired by human beings" (p.3) regardless of their languages, sexes or status. It can be said that, through this internalized linguistic systems, all human beings including those who learn another language have the ability to learn one or more language(s). Some theorists such as Ellis (2003) claimed that the internalized linguistic systems become the basic knowledge of NL learners when they start learning the TL. In other words, there is an internal mental process in TL learners' minds in which the TL learners subconsciously recall and use previously acquired knowledge of NL systems to relate and acquire new knowledge of TL systems (Bochner, Duchesne, Krause, \&
McMauch, 2010). It also showed the ability of humans' minds to "adapt to the new language and restructure their language systems" (Bowden, Sanz \& Stafford, 2005, p.125) and the capability of problem- solving in learning the TL (Vroman, 1989) including the ability of self-correction of TL errors.

Based on the cognitive approach above, Selinker (1972) as cited in Ellis (2003) believed that, after transforming process between the previous knowledge of NL and knowledge of TL system, the TL learners constructed cognitively a new knowledge of language system on the basis of their NL system. However, as Selinker continued, the new language system was somehow different either from the system of NL or TL. In other words, the new language system consists of some elements from NL and TL (Gass \& Selinker, 2008) and some of the elements are not likely to have come from the NL and TL systems (White, 2003). Similarly, it is also argued that "the 
learners are not fully distorting the NL system but inventing a system of their own" (Cook, 2001, p.16) so in some ways the new system is still based on the NL systems (White, 2003). This new language system is called as interlanguage (IL). The IL proposed by Selinker (as cited in Ellis, 2003) can be explained in this simple diagram below.

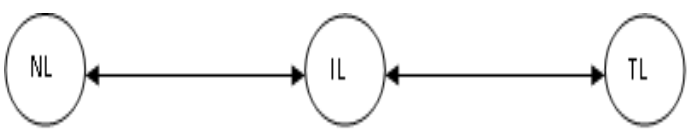

This diagram simply explains how the IL closely related to both NL and TL. Selinker (1972) suggested that, even though. IL is closely related to NL and TL, IL has its own independent system as a language. As an independent language system, it seems that, as shown in the diagram above, IL becomes a connector between NL and TL. However, Cook (as cited in Cook 2001) argued that the TL learners, on the one hand, have the knowledge of their NL; on the other, their IL knowledge in TL. Cook further claimed that the knowledge of both NL and IL of TL coexist in the learners' minds or "the knowledge of two languages in the same mind: one person knows both languages" (p.16). The combined knowledge of both NL and IL of TL in the same mind as viewed by Cook is called multicompetence. The following diagram described by Cook as the multicompetence:

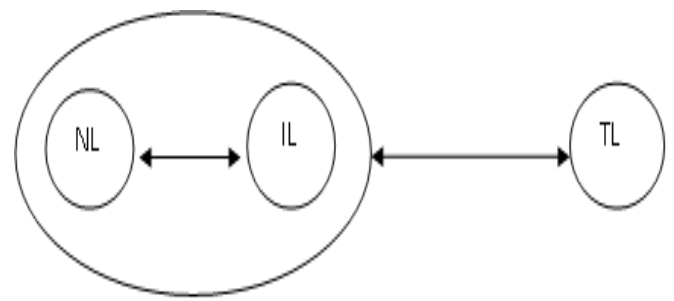

It is clear that the learners have already had the previous knowledge of NL as a very basic foundation to construct a new form and independent language system or IL when learning the TL. For instance, when non-English learners make errors without adding $-\mathrm{s}$ to the third singular verb of present tense e.g. "she speak English" instead of speaks, the learners built their own independent IL system. This sentence describes clearly and 
vividly the TL learning process in learners' internal structure minds and how the learners construct their own temporary knowledge of English as TL (Cook, 1993). Cook also argued that one of the reasons why some people see errors in TL as wrong is because the errors are measured against TL system. It is thus important, as Cook further argued, that the TL learners should not be assessed or judged their language acquisition like the TL speakers but as a sign of acquiring of their own IL. In addition, errors in IL should be considered either as an evidence of language development (Nicholas, Lightbown, and Spada, 2001) or as a trialand-error nature (Mizuno, 1991) which the later also lead to the TL learners' progress. Mizuno further added that the process of TL acquisition is pretty similar to the NL acquisition (young learners) as a trial-and-error nature. There is thus no right or wrong about the interlanguage errors (Gass and Selinker, 2008).
It is believed that TL learners employ various learning strategies to cope with their interlanguages errors (Coder, 1967\& Ellis, 1994). In other words, the different kinds of errors learners make, actually reflect different strategies of learning the TL. One of the strategies is omission. According to Ellis (1994, 2003) omission is a way of simplifying the learning task by ignoring grammatical features that they are not ready to process. Another thing, Skehan ( as cited in Han 2004) also found out that TL learners usually have natural tendency to emphasise on content, not on form. In addition, the omission was considered as an evidence of internal processing of the TL (Ellis, 2003) in order to construct their own language systems.

\section{METHODS}

This section presents the methods used in this study. It gives all detailed information about the participant, language feature, materials, data collection, data 
analysis and interpretation (Gass \& Mackey, 2005). It also includes how the procedure and analysis conducted in this research. In other words, all processes of this research will be briefly discussed in this section.

\section{Participant}

One participant is involved in this study. The participant is an Indonesian male (almost 31 years old). He has been in Australia for one and a half years accompanying his wife, who is completing a Master degree at a university in Australia. He started learning English when he was almost 12 year-old in Indonesia in his junior high school. However, he admitted that he did not have any interest nor motivation to learn English because it was difficult for him to learn English grammar. For example, he found it confusing to distinguish the English tenses such as simple present, future or continuous tense. As a result of this, he usually had difficulties to make good construction of sentences in English.

At this moment, he lives in Australia. He has been living in Australia for almost one and a half years. Nevertheless, he is not happy with his English progress. He still has the same issues as he experienced in SMP such as English grammar and vocabulary. $\mathrm{He}$ has difficulty speaking a sentence in English for two reasons; firstly, he has to listen carefully and nervously to what people have just said in English and, secondly, he has to think and translate to Indonesian language in his mind before he replies in English. He also shares that he feels differently when he speaks in English. In his native language, he used to speak fast and feel confident. Unlike when using his native language, he has to speak slowly and listen carefully and nervously in English. In other words, it is believed that he feels like a stranger when he speaks and listens in English. 


\section{Language feature}

This research analyses the participant's use of the 3rd singular pronoun in simple present tense. In simple present tense, the third singular pronoun e.g. he, she, it, Maria, John and etc. indicates repeated activities or durative verbs again until it becomes habitual (Evans \& Teschner, 2007). Evans and Tescher further explained that, in simple present tense, the third singular pronoun comes after verb. According to Radford (2004) the verb for the third singular person in simple present must be added with suffix -s, -ss or -es. For example, the uninflected base form of verb -eat is added with -s e.g. she eats two bananas every morning. Another example, "Maria goes to Coles every Sunday". The verb go is modified with -es.

Moreover, the reason to choose and use $3^{\text {rd }}$ singular pronoun in this research is that TL learners tend to omit $-s,-s s$ or $-e s$ in the $3^{\text {rd }}$ singular verbs of simple present tense (Ellis, 2003). For example, "she eat banana" without adding -s to the verb eat. Some theorists believed that omission of $-\mathrm{s}$ in the verb eat is a way to construct a new language system (Cook, 1993; Lightbown \& Spada, 1993; Gass \& Selinker, 2009). It is thus assumed that the participant in this study would omit $-s,-s s$, or $-s e$ in the $3^{\text {rd }}$ singular verbs. Unlike English, in Bahasa Indonesia there are no rules to add suffix $-s$, $-s s$ or $-e s$ to the $3^{\text {rd }}$ person singular verbs. In other words, the different rules of two different languages would lead to errors.

\section{Procedures}

First of all, the purpose of the study was briefly explained to the participant. After he demonstrated his understanding of the study, he would be given a brief instruction on how to answer the questions. He was instructed to use the third singular person e.g. she or my wife in simple present tense. After he clearly understood the instructions, he would be asked, with some questions previously prepared 
about his wife's daily activities. In his response, he was expected to use the third singular person e.g. she or my wife and simple present verbs e.g. cooks. It was also expected that the participant would answer the questions in complete sentences. For example, the question "What does she cook every night?" should be answered "She cooks rice" instead of just "rice". The main reason that he answered the questions in a complete sentence was to see whether the participant would add $-s,-s s$ or -es to the verbs. He was also asked for his permission to record the interview for data analysis. $\mathrm{He}$ was interviewed for 30 minutes about his wife's daily activities and his experience learning English.

\section{Analysis}

As the main focus of this research is IL analysis, it will first list and describe the IL patterns of simple present tense of third singular usage. Gass and Selinker (2008) categorized the IL patterns produced by TL learners as
English-like and non-English-like (errors) patterns of simple present of third singular usage. While the English-like refers to the structure of TL, non-English-like refers to IL. The first step is to identify the sentences produced by the participants based on the criteria of English-like and non-English-like. After identification, the second step is to analyse the kinds of language features (third singular of simple present tense) that are non-Englishlike produced by the participant.

\section{FINDINGS AND DISCUSSION}

In this section, the findings are presented with verbal descriptions of data. As can be seen in the interview transcript, in lines number 20 (she does), 40 (she does), 62 (he does) the boldface sentences are clear. These sentences are English-like because the have an es on the verb of $3^{\text {rd }}$ person singular. It is assumed that the participant knows the rules of adding suffix $-e s$ to the verb of $3^{\text {rd }}$ person (Radford, 2004). However, in lines number 10 (she wake up; she 
clean; she breastfeed), 14 (she make), 18 (she put), 24 (she like), 26 (she buy), 36 (she like), 44 (she cook), 46 (she cook), 52 (she always check), 56 (baby wake up), 60 (he drink), 62 (he need), 64 (he need) the participant does not add suffix $-\mathrm{s}$ to the verbs. These sentences are non-Englishlike (errors) because there is no $-s$ on the verbs.

The participant knows the correct rules the $3^{\text {rd }}$ person singular (in line 172 "ah...actually I know but ah ...mostly I forgot to use in conversation") but fail to use it consistently (Ellis, 1994). Even though, as he admitted, he knew the $3^{\text {rd }}$ singular rules, he forgot to use the correct systems in conversation (line 172). He further admitted that he did not know why he forgot the systems (line 178).

The participant seems to simplify the rules and forms of the language he learnt. In other words, he omits the suffix $-\mathrm{s}$ of $3^{\text {rd }}$ singular verbs e.g. in line 14 "she make" instead of "she makes". It is likely that the participant transfers the NL rules, systems, and knowledge to TL (Lado, 1957 as cited in Steilen (2005). In other words, it seems that NL (Bahasa Indonesia) and TL (English) share the same rules.

However, it is strongly believed that the participant made errors because he was constructing a new language system. The new system consists of some elements of NL and TL. It is also believed that the participant used the NL knowledge as a basic foundation to construct a new system when learning the TL. In other words, the knowledge of NL and TL coexist in the participant's mind. When the participant produces a sentence "she make", baby wake up or she cook" without adding the suffix-s, it shows the internal process of constructing a new system in the participant's mind. Cook believed that these sentences describe the temporary knowledge of English as TL.

The participant tended to omit -s e.g. she cook which is against the TL systems. Omission is one of the strategies to simplify the TL systems. According to Ellis (2004) 
the participant ignored the correct grammatical rules because the participant is not ready to process the correct rules. Ellis also considered that omission is a strong evidence of inventing a new language system.

One of the reasons why the participant omitted the $-s$ because he had to think what to say in English and sometimes he needed to translate, in his mind, from Bahasa Indonesia to English or vice-versa (in line 148 ..." but mostly to translate English to Indonesian uh...or Indonesian to English"). It is believed that the knowledge of Bahasa Indonesia and English coexist in the participant's mind. There is a strong possibility that the participant mixed the rules of both languages. The sentence e.g. "he drink" the participant produced is different from Bahasa Indonesia or English in terms of rules.

\section{CONCLUSION}

In conclusion, it is now believed that TL learners make errors due to some factors related to their TL and NL knowledge, systems and rules. These factors are coexist and interconnected in TL learners' minds. When the TL learners produce a TL sentence, the sentence which is called as errors is different from the TL and NL in terms of knowledge, system and rule. These errors reflect the ongoing process of the learners' minds. For instance, when a TL learner says "She play badminton every Saturday in sport centre", without suffix $-s$ in play, it describes a new structure of language construction in the TL speaker's mind. It is also similar to those who speak Spanish, Chinese or Arabic as their TL. In other words, it is the learners' efforts to construct their own new language construction (IL) which dissimilar either from NL or TLIt can therefore be seen that interference is not the main reason why the TL learners make errors. However, to some extent, interference still contributes indirectly when the learners make errors. For example, learners might possibly identify the 
error pattern when learning the TL. It is believed that by identifying the error patterns would help the learners to develop and master the TL.

When discussing these conclusions, it is always important to keep in mind the obvious limitations of this study. The study was conducted with a very small sample size ( 1 participant) over a very relatively short time scale (30 minutes). Therefore, data in this study may be unreliable. In order to have reliable data and also wider relevance conclusions, the study should be expanded to have more sample size over longer period of time. Having more samples and more time, it may possibly avoid perpetuating bias.

Finally, it is recommended that TL teachers should perceive errors made by the learners as a sign of language learning and development and therefore should not be discouraged. Also, TL learners should not be assessed or judged their TL language ability like the TL speakers. Also, it is strongly believed that TL teachers have very important role to help, guide and lead the learners' progress in learning the TL. Therefore, when the learners make errors, it means that the TL learners are trying to figure out and comprehend the rules of TL.

\section{REFERENCES}

Bochner, S., Duchesne, S., Krause, K.,\& McMauch, A., (2010). Educational psychology for learning $\mathcal{E}$ teaching ( $3^{\text {rd }}$ ed). China: China Translation \& Printing Services.

Bowden, H., Sanz, C., \& Stafford, A. (2005). Individual differences: age, sex, working memory and prior knowledge. In Cristina, Sanz (Ed.), Mind and context in adult second language acquisition (pp. 105-140). Washington DC: Georgetown University Press.

Cook, V.(1988). Chomsky's universal grammar: an introduction. Great Britain: Page Bros, Ltd.

Cook, V. (1993). Linguistic and second language acquisition: Modern linguistic. London: The Macmillan Press Ltd.

Cook, V. (2001). Second language learning and language teaching. $\left(3^{\text {rd }} \mathrm{ed}\right)$. London: Arnold 
Cook, V., and Newson, M. (2007). Chomsky's universal grammar: An introduction ( ${ }^{\text {rd }}$ ed). Australia: Blackwell Publishing Ltd.

Corder, P. (1967). The significance of learner's errors. International Review of Applied Linguistics 5, 161-170.

Ellis, R. (1994). The study of second language acquisition. Oxford: Oxford University Press.

Ellis, R. (2003). Second language acquisition. Oxford: Oxford University Press.

Evan, E., \& Teschner, R. (2007). Analysing the grammar of English (3 ${ }^{\text {rd }}$ ed.). Washington, DC: Georgetown University Press.

Gass, M.S., \& Selinker, L. (2001). Second language acquisition: An introductory course $\left(2^{\text {nd }}\right.$ ed). London: Lawrence Erlbaum Associates, Inc., Publisher. Retrieved:

http://books.google.com.au/ books?id=f77n3pJswDoC\&pg.

Gass, M.S., \& Selinker, L. (2008). Second language acquisition: An introductory course $\left(3^{\text {rd }}\right.$ ed. USA: Sheridan books, Inc.

Han, Z. (2004). Fossilization in adult second language acquisition. Great Britain: Cromwell Press Ltd.

Hytelstam, M \& Pienemann, M (1985). Introduction. In Hytelstam, M \&
Pienemann. Modelling and assessing second language acquisition. Great Britain: Short Run Press, Ltd. Retrieved from: http://books.google.com.au/book s? id=8uXBeeVdsKsC\&pg=PA6 $\& \mathrm{dq} \# \mathrm{v}=$ onepage $\& \mathrm{q} \& \mathrm{f}=$ false

Langacker, R.W. (1987). Foundations of cognitive grammar: Theoretical prerequisites. Standford, California: Stanford University Press.

Lightbown, P., \& Spada, N. (1993). How language are learned. Oxford: Oxford University Press.

Lyons, J. (1977). Chomsky. Great Britain: Harvester Press Limited.

Mackey, A., \& Gass, S. (2005). Second language research: Methodology and design. USA: Lawrence Erlbaum Associates, Inc.

Mizuno, H. (1991). How to analyze interlanguage errors. Japan: Kanagawa University.

Nicholas, H, Lightbown, P,. \& Spada, N. (2001). Recast as feedback to language learners. Language learning 51(4), 719758.

Pienemann, M. (2003). Language processing capacity. In Catherine, J. and Michael, L (Eds). The handbook of second 
language acquisition (pp. 679714). Oxford: Blackwell. Retr ieved from: http:/ / eric.ed. gov/PDFS/ED374655.pdf

Radford, A. (2004). English syntax: An introduction. United Kindom: Cambridge University Press.

Selinker, L.(1972). Interlanguage. International Review of Applied Linguistic 10, 209-231.

Steilan, A. (2005). The influence of consonants on native and nonnative vowel production: a cross linguistic study. Germany: Druck and Verarbeitung Llprint. Retrieved: http:/ / bo oks.google.com.au/books?id= X2GOnU-nfDIC\&pg=PA32\& dq.
VanPatten, B., \& Benati, A. (2010). Key terms in second language acquisition. Great Britain: MPG Books Group. Retrieved from: http:/ / books.google.com.au/ books?id=KO-ZDi_lpYIC\&pg $=$ PA82\&dqe\# $\mathrm{v}=$ onepage $\& \mathrm{q} \& \mathrm{f}$ $=$ false

Vroman, R. (1989). What is the logical problem of foreign language learning?. USA: Cambridge University Press.

White, L. (2003). Second language acquisition and universal grammar. United Kingdom: Cambridge University Press. 